\title{
Curriculum hidden: Contemplating more-than-human ethics
}

\author{
Lee Beavington \\ Kwantlen Polytechnic University \& Simon Fraser University
}

\begin{abstract}
Homo sapiens rationalize their species' uniqueness to justify anthropocentrism and selfinterest towards nonhumans. Research and pedagogical practice such as mandatory dissection and animal experimentation, alongside mechanistic and atomistic assumptions deeply embedded in science curricula, reinforce the idea that nonhuman animals lack moral status. We need to devise and implement holistic, place-based curricula in our schools, where ethics are part of the conversation before students use nonhuman animals in their learning and research. Synergy and deep ecology can move us from exclusively biotic morality toward a more inclusive abiotic morality.

environmental ethics; speciesism; ecocentric pedagogy; philosophy of education; biology education
\end{abstract}


the same breath taken by butterfly

curses the infant caterpillar

feather and leather-bound adorn our plates

while furry friends are seldom factory farmed

what separates the pampered purr

from the feline parted from her dissected organs?

\section{Flagging Our Species' Specialness}

Historically, philosophers, scientists, linguists, politicians, religious leaders and educators have distinguished the human species from all others. Self-awareness, tool making, language acquisition, ability to feel emotion and pain, and many other rationalizations legitimize that special status taken for granted by Homo sapiens, often with the result (whether intentional or not) of giving legal and/or moral rights for human exploitation of every other creature that isn't a relatively hairless bipedal primate.

As author Michael Pollan (2013) writes, we are obsessed with identifying the faculties unique to us:

One by one, the faculties on which we thought we could stake the flag of our specialness science has shown belong to other animals as well. Suffering?

Reason? Language? Counting? Laughter? Self-consciousness? All have been proposed as human monopolies, and all have fallen before science's deepening understanding of the animal brain and behavior...though perhaps an even sturdier candidate would be this: humans are the only species that feels compelled to identify faculties that it alone possesses. (p. 55-56)

One uniquely human aptitude I would add is our capacity to drastically alter our environment. By staking "the flag of our specialness" we grant our species rights and privileges to factory farm our food, engage in vivisection and animal research, trawl the seafloor, and clear cut entire habitats of wildlife for our species' sole benefit. Should our self-interest concede the suffering and killing of nonhumans? On what ethical basis have we situated ourselves in this place of moral privilege? Even the very definition of a species is highly variable and ardently contested by biologists and philosophers (Wilkins, 2009). If our specialness is an arbitrary invention, and there exists "a serious asymmetry of power and capacity between the creatures" (Nussbaum, 2006, p. 22), then we need to rethink and deconstruct our anthropocentric worldview.

In this paper I will argue that science education, with its mechanistic and "highly partial and reductionist" (Bonnett, 2009, p. 182) approach, promotes an intellectual dissociation and general desensitization to nonhumans. By flagging our specialness, we become separate from, rather than a part of, the Earth's ecosphere. This places humans in a category unto themselves wherein we lose our "ecological literacy" (Cohen, 2007, p. 118). Forgetting and neglecting our symbiotic relations with other species supplants mutualism with a "union of the theoretical and empirical approaches to our natural environment" (White, 2004, p. 193) whereby utilitarian animal use and resource extraction benefits only the human party. When we lose our "ability to empathize and identify with nonhuman life" (Metzner, 1995, p. 61), we also lose our respect and humility for the mysteries of the natural world, resulting in scientific and economic gain being valued above social and environmental considerations. Science curricula rarely engages with the 
ethics of science, often focused on how to experiment, dissect and atomize and rarely questioning if we should. Leopold (1949) asks the pertinent question: "Is education possibly a process of trading awareness for things of lesser worth?” (p. 18). We need to find a path toward holistic education-one that is experiential, embodied, and reciprocative-where ethics are part of the conversation before students use nonhuman animals in their learning and research.

First I will elaborate on the self-interested, and sometimes arbitrary, fashion with which we approach animal use and the ethics therein, and how limiting moral rights to humans sanctions enormous nonhuman suffering. Next I will explore how our science pedagogy is embedded with anthropocentrism, and how teaching practices such as mandatory dissection assumes and reinforces the idea that nonhuman animals are devoid of moral status, or at least given lower moral status. Finally, I will outline a conceptual basis for moving toward Leopold's (1949) ecocentrism, what Panikkar (1996) describes as "Peace with the Earth [that] excludes victory over the Earth, submission or exploitation of the Earth to our exclusive needs. It requires collaboration, synergy, a new awareness" (p. 57).

\section{The More-than-human Conversation}

As David Abram (1996) asks, "How did Western civilization become so estranged from nonhuman nature, so oblivious to the presence of other animals and the earth, that our current lifestyles and activities contribute daily to the destruction of whole ecosystems?" (p. 137). If utilitarianism strives to do the greatest good for the greatest number, this is clearly exercised with extreme prejudice from those who philosophized it into being (because the focus is on human good, and nothing but the human good). Thompson (1997) outlines how "ecological abuse [and] animal suffering [are problems] caused by the one-sidedness of a public sphere orientation that emphasizes self-advancement over relational responsibility" (p. 329-330). Our interactions with nonhumans resemble an asymmetrical marriage where one partner exploits and the other lacks any inherent rights.

Nussbaum (2006) paraphrases Aristotle's assertion thusly: “all animals are akin, in being made of organic materials; humans should not plume themselves on being special" (p. 348). The ecology of our existence is utterly dependent upon our relationship with the more-than-human world (Abram, 2011), and yet science has still to describe $75 \%$ of Earth's animal and plant species. When we walk through the forests of the Pacific Northwest, more life (in terms of species number, biomass, and organic activity) exists beneath our feet than above. An old growth Douglas-fir has just as much mass invisible to our eyes as that which towers to the canopy overhead, while a single grass specimen boasts 14 billion root hairs that stretch 10,000 kilometers (Luoma, 2006). Every step we take is on the back of 16,000 invertebrates (insects, millipedes, and roundworms among countless others) and each pinch of soil holds hundreds of millions of bacteria vital to the decomposition process without which the Earth would be a vast garbage dump of dead organisms many times over. The vast network of life hidden to our eyes, so easy to ignore, is what helps sustain biological life.

By example, the tiny tardigrade (commonly called the water bear) is ubiquitous on our planet, estimated to be seven billion billion in number, yet many humans are unaware of their existence and the significant ecological role they play in myriad ecosystems. If a tardigrade could communicate with a human through the English language, perhaps a conversation on the topic of species specialness would sound something like this:

Human: We humans can survive on every continent.

Tardigrade: What about under the ocean? To us, hydrothermal vents are like Florida. 
$\mathrm{H}$ : Er, we don't do well in water for long periods. But we've been in space!

$\mathrm{T}$ : You can survive in the vacuum of space? Me too!

$\mathrm{H}$ : Not exactly, we need our spacesuits. What with the intense solar radiation, absolute zero temperatures, and utter lack of oxygen...

$\mathrm{T}$ : Those don't bother us much. We can go dormant for 10 years. Or even be put in boiling water. We'll still reproduce!

$\mathrm{H}$ : Okay, but where are your civilizations?

T: There are a billion of us for every one of you. We're fine with moss.

$\mathrm{H}$ : We've changed the world to fit our needs.

$\mathrm{T}$ : Oh, you've made more moss?

H: No, no-

T: More oxygen? Old growth forest? Increased biodiversity? A more hospitable climate?

$\mathrm{H}$ : You're missing the point. Hey, where are you, anyway? I can't see you.

T: Here, in this dew drop. Try putting me under a microscope.

$\mathrm{H}$ : Okay...wait, you have eight legs?

T: Four more limbs than you.

$\mathrm{H}$ : You think that makes you superior?

T: Only different.

In order to use animals the way we do, we need to feel superior to them; put another way, we bestow virtues and morals to our species and omit them from others, consequently causing harm for our benefit. We have made ourselves into a pseudo-keystone species whose worth eclipses every other. This line of thinking is antithetical to holistic ecology science.

Two important items should be addressed here. The first is that nonhuman animals obviously can't speak English. There is strong evidence that some of the more complex mammalian species, such as dolphins and gorillas, do have a rudimentary form of language. Koko the gorilla has even been taught sign language, with a vocabulary of over one thousand words (Patterson, Tanner \& Mayer, 1988). Yet such "language use is a frill, constructed by human scientists; [nonhuman primates'] own characteristic mode of flourishing in their own community does not rely on it" (Nussbaum, 2006, p. 364). Secondly, nonhumans do not philosophize the way humans do, nor can they engage in a conversation on ethics. But this should not exclude them from some form of rights. After all, young children and the mentally disabled cannot articulate and understand ethics either.

If being human confers moral status; that is, possessing the specific 23 sets of chromosomes that results in the phenotypic totality of what it means to be human-then it does not matter what genes and traits nonhumans possess. If intelligence, community living, and the ability to feel pain, empathize and express emotion (all qualities shown by nonhumans) do not confer moral status, is this not an utterly arbitrary distinction made at the genetic level? Our reliance upon other species gives us good reason to protect the more-than-human, a point I will return to later in this paper.

\section{Ecology and Ethics}

The word ecology, derived from the Greek oikos, means household or family. Every ecosystem is a home to intricately interconnected organisms, and since the first law of ecology is that "Everything is connected to everything else" (Commoner, 1971, p. 16), it stands to reason that humans are tied to many other organisms. However, the way we use the word animal suggests that we are referring to something other than human; that is, something less evolved or inferior in some way, all the while conveniently forgetting that humans hold membership to Kingdom 
Animalia right alongside the lowly worm. "If life has a meaning only for the victors, only for those who 'make it,' we create an artificial hell for all the others" (Panikkar, 1996, p. 52). This artificial hell is justified because only humans fall under the moral umbrella. Yet the root of the word animal, anima, means breathing, soulful being; this suggests that an animal is a being endowed with spirit rather than a debased entity subordinate to humans.

When Noddings (2002) asks the question, "If we have established a caring relation with one person at the cost of weakening a larger web of care, can we be said to have cared?" (p. 30) we can, in turn, extrapolate this to a larger, ecological context. In striving to care for one species, we weaken the larger web of organisms, and neglect to care for them-much, I will argue, to our own detriment.

As Nussbaum (2006) points out, "We humans share a world and its scarce resources with other intelligent creatures" (p. 325), and such intelligence is adaptively unique to each species. "Our choices affect the lives of nonhuman species every day, and often cause them enormous suffering. Animals are not simply part of the furniture of the world; they are active beings trying to live their lives; and we often stand in their way" (p. 22). Our human animal needs come first, but at what cost?

One of the most systematic sources of suffering perpetrated on nonhumans by humans is the raising and killing of livestock. Humans are heterotrophs; by our biology we must eat to survive. A vegan lifestyle limits this consumption to members outside of Kingdom Animalia. But for the sake of argument, let us say that a human must consume the meat of an animal in order to live a healthy life. In this case, the death of another animal is necessitated by our gastronomical need. Should we not raise these animals in such a way that their suffering is limited?

Factory farmed chickens pumped full of growth hormone wading in their own feces, and pigs unable to turn around in their enclosures, never to touch grass or feel sunlight, seems utterly contrary to this notion. Yet millions of animals are kept and killed in such conditions every day, well hidden from the public eye. When we buy precut, preprocessed, prepackaged meat at the grocery store, we have removed ourselves from the suffering and blood that went into this plastic wrapped product. Panikkar (1996) describes how "The animal does not 'kill,' it eats. Man does not exploit when following Nature; it grows and evolves” (p. 57). Gary Snyder's (Bromige et al., 1968) poem, "Song of the Taste," (p. 359) eloquently elucidates upon this idea,

Drawing on life of living clustered points of light spun out of space

hidden in the grape.

Eating each other's seed eating ah, each other.

Kissing the lover in the mouth of bread: lip to lip.

In this view, we can celebrate eating as an ecological act; but the way we eat needs to be ethically examined. What if each of us had to care for, grow, and slaughter our own animal food? The question I ask myself is, Could I kill, process and cook a chicken, goat, pig or cow in order to consume it? The answer for me is no, and I am therefore vegetarian. As long as we identify 
nonhumans as beings who cannot suffer, and who have no moral rights, we will not care for their well-being. Epistemologically, we seem unable to see nonhuman animals as beings who are entitled to moral rights. This is partly convenience, partly prejudice, and partly how we are built: for the duration of the human species, we have used other animals in order to survive. Now, our survival may very well depend on monitoring, regulating, and curbing this exploitation of the more-than-human world.

The use of animals in science teaching and research is another utility that benefits our species, obliging the suffering of another. Frogs and other vertebrates are dissected in North American classes as a matter of course, and while no reliable numbers are available, the existing data suggests that at least six million such animals (many wild caught, in the case of frogs) are used every year for dissection in USA high schools (Animalearn, 2012). Meanwhile, countless other nonhuman animals are experimented upon for medical research, the benefit of which is inestimable: our understanding of and treatments for heart disease, diabetes, epilepsy and a host of other conditions have improved dramatically (Americans for Medical Progress, n.d.). Therefore, the unfortunate pain and ending of nonhuman animal life is justified for the Homo sapiens' good. Of course, there is a wide spectrum of animal uses in research, from cosmetics placed on the eyes of rabbits to rats used for cancer studies; the former, more easily categorized with vanity, is not as morally sound as the latter, whose results could produce a cure that saves millions of human lives annually.

In science, model organisms are those that are easy and cheap to care for, and whose anatomy or behaviour is readily extrapolated to the human species. Studies on species that closely mimic our biology give more dependable and meaningful results for humans. For a moment, let us imagine a science-fiction scenario (remembering that science fiction is literature that is not true, but could theoretically be). If an alien species a thousand times more evolved than humans came to Earth, and found that humans possessed some key physiological quality that allowed them to experiment upon us to their great gain, would we object? I am certain that we would. Some may argue that both humans and these advanced aliens possess a quality-and thus a moral status-that separates us from the rest of animals, and so humans should still be exempt from being the subject of experimentation. The problem here is that humans (and the aliens in their case) decide to arbitrarily draw the line at their own species. Perhaps chimpanzees-or, for that matter, jellyfish-given the capability, would do the same. Such arbitrary delineation is based on subjective self-regard, and is morally dubious, as similar intraspecific arbitrary distinctions helped bring about slavery, cultural genocide of native peoples, and the Holocaust.

Christian morality posits that humans are meant by God to dominate the world and use other species for human benefit. In a secular context, some ethicists maintain that humans have greater moral rights. Both are human-oriented perspectives founded on our consciousness and 'uniqueness' granting us greater moral rights. Since, to the best of our knowledge, certain nonhuman animal species are sentient, able to feel pain, live in community, even laugh and cry, what trait can we use to separate Homo sapiens from the rest? The list becomes thin and capricious. As humans we have decided, by and large, that only humans possess moral status. If we are so special, so unique, and so privileged, how then can we justify the current genocide of the natural world?

"What less often comes to mind...is the need to extend our theories of justice outside of the realm of the human, to address issues of justice involving nonhuman animals" (Nussbaum, 2006, p. 21). For this to happen, humans would need to make innumerable sacrifices. If it is wrong that nonhuman animals suffer, and that millions die daily for our research and dietary needs, to recognize and halt this suffering would require a paradigm shift in terms of how 
humans eat, teach, research and live their everyday lives. But if all of this suffering meant that your own child would be saved from a certain fatal disease, would you still side with the nonhumans? These are the kinds of difficult questions we need to ask.

\section{Why Care About Nonhumans?}

Ecological problems can overwhelm the progress made in the area of social justice. Historically speaking, western society has made only recent provisions to protect the rights of those long underprivileged. Equal rights for women, people of different ethnic backgrounds, the physically and mentally challenged, and the LBGTQ community are relatively new concepts for our species (and in most, if not all, of these cases systemic discrimination is still widely prevalent). Therefore, an argument could be made that we need to sort out the ethics and legalities of our own species first before attempting the same with nonhumans. However, this again conveniently limits our philosophical focus to ourselves. Regardless of whether or not nonhuman animals (or other organisms, for that matter) are given moral consideration, a strong (and vital) argument can be made for our dependency upon the other-than-human world. All of our basic necessities are derived from the natural world: food, shelter, clothing, energy, medicine, and that invisible and miraculous gas exhaled by leaves we call oxygen.

Our planet's biosphere houses 8.7 million species (Mora et al, 2011), excluding countless bacteria and viruses. Narrowing our focus to the human body, our best estimates indicate that we are composed of up to 100 trillion cells, and yet more than half of these are bacterial (Sender, Fuchs, \& Milo, 2016). This means that the human ecosystem, shared with more than 40,000 species, houses more nonhuman than human DNA, yet because this otherness does not appear to us in a way that we can consciously register, we cling onto an anthropocentric worldview. Our intimate connections with other forms for life should have us call into question what it means to be human and reevaluate the boundaries of human selfhood. By extension, we should care about nonhumans because, even though they are in one sense an other, in another, somewhat paradoxical sense, they are not separate from us.

Finite resource extraction, habitat degradation, species extinction, climate change, essentially the cumulative pollution of land, water and sky calls for an urgent shift in cultural and ideological principles. Clearly humans can and do benefit by conserving and protecting the rights of other species. However, this should not preclude the idea that other species should be protected in their own right, an idea I will return to at the end of this paper.

\section{Speciesism and Our DNA}

If your pet dog is made to suffer, your moral outrage will be greater compared to a stray dog that has no such human association. One may argue that, similarly, if your brother is made to suffer you will be more outraged than if a homeless person is made to suffer. Both are true; the closer ties we have to a living organism, the greater our empathic connection, and thus the more we are affected by its suffering. However, speaking from the perspective of ethics, in both such cases the animal (whether canine or human) that has no direct relation to another human should be protected from suffering regardless. Pain and distress are not tolerable simply because they fail to be witnessed, nor are they permissible because it is a different species that suffers. Yet humans in general have a tendency to show more apathy and less compassion for those with which they are less familiar.

Table 1. The genomic differences of Homo sapiens compared to other organisms (including other humans). The genomes of those organisms that have been sequenced are either edible or model organisms in scientific studies. Much of geneticists' time and resources are spent 
analyzing the genetic information of species that serve to benefit humankind. That is, our research path follows the utility. (Adapted from Pontius et al. 2007 and Zimmer, n.d.)

\begin{tabular}{c|c} 
Species & $\begin{array}{c}\text { Percentage } \\
\text { difference in DNA } \\
\text { from humans }\end{array}$ \\
\hline Human & $0.5 \%$ \\
Bonobo and chimpanzee & $1.2 \%$ \\
Gorilla & $1.6 \%$ \\
Orangutan & $3.1 \%$ \\
Cat & $10 \%$ \\
Dog & $18 \%$ \\
Cow & $20 \%$ \\
Fruit Fly and chicken & $40 \%$ \\
Wine grape & $76 \%$ \\
Baker's yeast & $82 \%$
\end{tabular}

While we might be reluctant to cause unnecessary harm to other primates, who differ only slightly in their DNA constitution, one would be hard pressed to find a human who shows any reluctance in how they use Baker's yeast. Going up the rows in Table 1, we increase the likelihood of moral consideration as we move from plant, to livestock, to pets, and finally the apes. Even so, the owner of a golden retriever would be loath to inoculate their pet with HIV, while chimpanzees are the model species for such research.

Based on the information in Table 1, we might claim that we will only experiment on those animals whose DNA differs from humans by at least $1.2 \%$, which distinguishes us from our closest genetic relatives, the chimpanzee and bonobo; the former passes down learned skills to their young, while bonobos have shown creative musical ability (May, 2013)-both characteristics long thought to be strictly human. However, it is not genomic disparity that neglects the rights of others, but the fact that we classify someone as human that grants them special status not reserved for any other species. (In fact, not considering African Americans to be human ensured slaves did not need to be given their constitutional rights, explained away by declaring them "nonhuman" or "sub-human.")

Chimpanzees have been used in a plethora of psychological and medical experiments. Being our closest living relative, their bodies mimic our own better than any other species. The alternative viewpoint here is that, rather than treat our primate cousins the same way we treat an experimental rat (or yeast), we should grant them rights closer to our own. Since their suffering matters (and parallels human suffering closer than any other animal species), they should be considered moral agents. Something is ethically remiss when our closest genetic relatives, 
possessing many human attributes such as language, community, and tool making, are made to suffer and die for our benefit.

"Killing a mosquito," Nussbaum (2006) contends, "is not the same sort of harm as killing a chimpanzee" (p. 359). Other primates possess sentience, the ability to make conscious choices, which is how Peter Singer (1975) argues for selective animal rights. He uses the example of a human with Down's syndrome possessing fewer mental faculties than a bright chimpanzee. If we won't experiment on a human with Down's syndrome, we should also not experiment on a chimpanzee, as doing so is speciesism-that is, discrimination based on species.

Nevertheless, suffering alone should be enough to consider the moral rights of nonhumans. If suffering matters, and if humans choose to cause suffering for nonhumans (to benefit Homo sapiens) in an arbitrary manner, we need to reevaluate how we think about and treat otherthan-human species, and consider the ramifications for education and curriculum. How can we embed an experiential learning model that inspires an ecocentric ethic? Within such a pedagogical system, how do we avoid speciesism and disrupt anthropocentrism?

\section{The Curriculum Connection}

Many scientific (and inherently atomistic) assumptions are deeply embedded in our curriculum. When a dead frog is placed in front of a biology student, the implicit statement is that this hourlong lesson is more important than the life of this frog. Science as epistemology assumes, almost as a matter of course, that this animal is an object and its internal organs mechanisms to be atomized and studied. The frog becomes more object than organism, devoid of moral status. In this way, science education can construct nonhuman nature as inert and therefore not worthy of ethical consideration.

Proponents of frog dissections may contend that dissection is hands-on, a literally visceral experience oft-remembered by students. In addition to discussing and relating organ systems to human anatomy, such a lesson can be interwoven with concepts of evolution (such as adaptations linked to leg and tongue length) and ecology (such as habitat and ecological niches). One might also argue that dissection can inspire future surgeons or veterinarians to pursue such careers. Further, there is an enormous invasive American bullfrog population that needs to be stymied (Louette, Devisscher, \& Adriaens, 2014); catching such amphibians in order to remove them from non-indigenous areas and providing these specimens to be used in dissections makes good use of an ecological problem.

However, such reasoning does not, in itself, justify the killing of these animals. None of these reasons address the underlying issue of engaging the world through a human-centered lens, and therefore enabling the arbitrary suffering of nonhumans. The problem goes deeper than what students can learn from dissections. We need to address the hidden curriculum and unspoken presumptions that happen as a result of mandatory dissections. Dissection invariably moulds the young minds of students given scalpels as tools.

While science does follow its own set of ethics-an unbiased and honest approach with responsible results that get peer-reviewed-the use of animals is a given in the biological sciences. Bioethics is a discipline concerned with the ethics of science, yet while we may be persuaded to be efficient in our use of animals (Festing et al., 2002), such use is, in many ways, the backbone of biology. In order to study life, we experiment upon and dissect nonhuman life. 
When dissections happen, the specimen is already dead and located in a sterile (e.g., not its natural) environment. By negating choice, that is, "by [our] silence on the subject" (Martin, 1981, p. 107) this impresses (or even imposes) a certain moral viewpoint on students. One wonders how many biology students graduate without a single "worry about the uses to which [science] is put" (p. 104). More broadly, educators often neglect to "investigate the particularly acute and very challenging value questions that arise in relation to hidden curricula of all kinds" (p. 108).

Goethe expressed concern that

to break phenomena down into discrete elements or units is to drain them of life. Life resides in wholes: when organisms are taken apart they are no longer alive. In order to understand, and hence engage with, the aliveness of nature, we have to understand it in terms of its wholeness. (Mathews, 2008, p. 60)

The frog is more than the sum of its parts. The fact the animal is dead omits a significant-and imperative-part of the lesson. Ecology has a lot to teach the other sciences: the interrelatedness of all things is a pertinent concept to shift our worldview toward a more holistic, ecological perspective. Many scientists have deep moral concerns for the nonhuman members of the biosphere, yet all too often this concern arises from an anthropocentric perspective.

How can we approach frog dissections differently? A number of options are available, including (1) giving students the choice to dissect or not. This can include a discussion prior focused on the benefits and drawbacks of dissection, as well as the available alternatives (such as models and online dissections). (2) Moving the classroom outside into a place-based learning environment, where frogs are part of the ecosystem. One can imagine a very different lesson being taught by those students given a dead frog and a scalpel, and those who discover this living and breathing amphibian in its own environment. The former focuses on anatomy and physiology, the latter on ecology and habitat, shifting from anthropocentric to ecocentric attitudes. (3) Widening our scope, ethics and a sense of social responsibility can be interwoven with many, if not all, lessons. This helps undermine intrinsic speciesist assumptions about what and how we learn. Of course, the above options are dependent upon the age group of learners, available technology, and access to wetland habitat. But with computers being ubiquitous at schools, and online simulations getting more and more sophisticated, dissection alternatives have never been closer to the real thing.

Situations may exist where dissection is ethically defensible. If animal specimens, dead of natural causes, are found in their native environment by students, this gives learners an ecological context. Further, the gathering, preparation, dissection and cleanup of the specimen(s) would be carried out respectfully, with a reverence and gratitude for this opportunity, with students involved and giving input at every step.

\section{Looking Forward to an Ecocentric Education}

This paper has primarily focused on human and nonhuman animal ethics. However, a case is increasingly made for extending ethical consideration not only for all living things, but for inanimate objects as well (Curry, 2011). This is the realm of deep ecology, and although I do not have room to explore this fully, I feel that a brief glimpse at the path ahead is pertinent.

When economic gain consistently trumps environmental ethics, the importance of nature and ecology is overlooked. As Leopold (1949) so clearly prophesied more than half a century ago, 
"our bigger-and-better society is now like a hypochondriac, so obsessed with its own economic health as to have lost the capacity to remain healthy" (p. ix). Panikkar (1996) contends that, "To have to pay for water, food-and soon even air-is a sign of a sick culture" (p. 51). Given that each human is a "knot in a net of relationships," (p. 55), and since "Aristotelians argued that all of nature is a continuum, and that all living creatures are worthy of respect and even wonder" (Nussbaum, 2006, p. 328), only an ecocentric worldview can help establish such respect and wonder for the more-than-human.

We need what Mathews (2008) calls,

a creative co-action, a form of co-action that might be termed synergy [which is] any form of intentional interactivity between two or more parties who engage with each other in such a way that something new and larger than either of them, but true to the inner principle of each, is created. (p. 48)

I would argue that the human body, as a living and breathing ecosystem containing trillions of bacteria, fungi, protists, and tiny animals, is such a synergy. Our own welfare is tied to the flourishing of many ecosystems containing both animate and inanimate members; we thus have ethical obligations to entire ecosystems, up to and including the entire planetary oikos. Mathews' synergy concept would enable the import of ecological concerns to move toward the forefront of human thought and progress, and to see "our beliefs as living convictions rather than dogmatic formulae" (Callan, 1995, p. 30).

Synergy and deep ecology move us from exclusively biotic morality toward a more inclusive abiotic morality. "Every natural being is a living cell forming part of a whole and mirroring the whole at the same time. Not only animals and plants are alive, so are mountains and rocks" (Panikkar, 1996, p. 56). Taken this way, even the inorganic elements of the biosphere, from rivers and oceans to minerals and earth, become worthy of moral consideration.

The classroom, as the site of learning, has a pivotal role to play here. Sitting in rows with the authority figure in front sets the stage for learners to be passive and attentive. Learning begins when the first bell rings, and pauses when the recess bell goes off. Prescriptive lesson plans keep surprise and spontaneity to a minimum. Everything is neatly contained in one room. Contrast this with an outdoor classroom, and the conditions dramatically shift. Control is traded for stimuli, walls for sensorial experience, desks for embodiment, moving toward "embodied teaching and learning wherein the whole personality and life of the teacher and learner are involved" (Bai, 2006, p. 17).

Student curiosity is further engaged and the unexpected (whether in the form of clouds, rain, ants, birds or myriad other natural phenomena) gets incorporated into the curriculum of the day. Lessons have a greater potential to become interdisciplinary, cross-pollinating across subjects. While student 's can benefit from the increased movement and participation of learning outdoors, recent evidence suggests that educators who teach outdoors develop innovative teaching strategies, in addition to bolstering their confidence and enthusiasm for their work (King's College London, 2011). Pedagogy needs to involve the creation and maintenance of a moral climate of care, respect, sensitivity, and compassion whereby class members become more attuned to and connected with all those who are other (Bai, Cohen \& Scott, 2013; Cohen \& Bai, 2012). 
"That land is a community is the basic concept of ecology, but that land is to be loved and respected is an extension of ethics" (Leopold, 1949, p. viii-ix). Can we learn to love and respect what we treat as mere commodities? Further, we must protect and care for entire ecologies based on our recognition that we are inextricably connected to them; their welfare and flourishing is our own. The long trodden road of anthropocentrism leads us to protect a salmon species-but not the river they swim, feed, mate and nest within. A world where rivers are treated with wonder and respect is also a world where students learn outdoors through an ecocentric lens. 


\section{References}

Abram, D. (1996). Spell of the sensuous: Perception and language in a more-than-human world. New York: Vintage Books.

Abram, D. (2011). Becoming animal: An earthly cosmology. Toronto, ON: Random House of Canada.

Americans for Medical Progress. (n.d.). Animal research benefits: Animal research means medical progress. Retrieved from https://www.amprogress.org/animal-researchbenefits

Animalearn. (2012). Frequently asked questions: How many animals are dissected every year? Retrieved from http://www.animalearn.org/faq.php\#.VSqp1EvdJ_u

Bai, H. (2006). Philosophy for education: Towards human agency. Paideusis 15(1), 7-19.

Bai, H., Cohen, A., \& Scott, C. (2013). Re-visioning higher education: The three-fold relationality framework. In J. Lin, R. Oxford \& E. Brantmeier (Eds.), Re-envisioning higher education: Embodied paths to wisdom and social transformation, Charlotte: Information Age Publishing.

Bromige, D., Eigner, L., Langland, J., Sandeen, E., Snyder, G., Sorrentino, G., Stafford, W. E., \& Stefanile, F. N. (1968). Poetry 111(6): 359.

Callan, E. (1995). Virtue, dialogue, and the common school. American Journal of Education 104(1), 1-33.

Cobb, E. (1977). The ecology and imagination in childhood. New York, NY: Columbia University Press.

Cohen, M. J. (2007). Reconnecting with nature: Finding wellness through restoring your bond with the Earth. Lakeville, MN: Ecopress.

Cohen, A. \& Bai, H. (2012). Minding what really matters: Relationship as teacher. In Chambers, C. Hasebe-Ludt, E. Sinner, A. \& Leggo, C. (Eds.), A heart of wisdom: Life writing as empathic inquiry (pp. 257-266). New York, NY: Peter Lang.

Commoner, B. (1971). The closing circle: Nature, man, and technology. New York, NY: Bantam Books.

Curry, P. (2011). Ecological ethics. Cambridge, UK: Polity Press.

Festing, M. F. W., Overend, P., Gaines Das, R., Cortina-Borja, M., \& Berdoy, M. (2002). The design of animal experiments: Reducing the use of animals in research through better experimental design. London: The Royal Society of Medicine Press Limited.

King's College London. (2011). "Understanding the diverse benefits of learning in natural environments." Retrieved from http://www.lotc.org.uk/wpcontent/uploads/2011/o9/KCL-LINE-benefits-final-version.pdf 
Leopold, A. (1949). A sand county almanac and sketches here and there. Oxford, England: Oxford University Press.

Louette, G., Devisscher, S., \& Adriaens, T. (2014). Combating adult invasive American bullfrog Lithobates catesbeianus. European Journal of Wildlife Research 6o(4), 703-706.

Luoma, J. R. (2006). The hidden forest: Biography of an ecosystem. Corvallis, OR: Oregon State University Press.

Martin, J. R. (1981). The ideal of the educated person. Educational Theory 31(2), 97-109.

Mathews, F. (2008). Thinking from within the calyx of nature. Environmental Values 17, 41-65.

May, K. T. (2013, Feb. 28). The interspecies internet: Diana Reiss, Peter Gabriel, Neil Gershenfeld and Vint Cerf at TED2013. Retrieved from http://blog.ted.com/2013/o2/28/the-interspecies-internet-diana-reiss-peter-gabrielneil-gershenfeld-and-vint-cerf-at-ted2013/

Metzner, R. (1995). The psychopathology of the human-nature relationship. In T. Roszak, M. E. Gomes \& A. D. Kanner (Eds.), Ecopsychology: Restoring the Earth, healing the mind (pp. 55-67). San Francisco, CA: Sierra Club Books.

Mora, C., Tittensor, D. P., Adl, S., Simpson, A. G. B., \& Worm, B. (2011, August). How many species are there on Earth and in the ocean? PLOS Biology. doi: 10.1371/journal.pbio.1001127

Noddings, N. (2002). Starting at home: Caring and social policy. Los Angeles, CA: University of California Press.

Nussbaum, M. C. (2006). Frontiers of justice: Disability, nationality, species membership. Cambridge, MA: The Belknap Press.

Panikkar, R. (1992). A nonary of priorities. Interculture, XXIX(1), 48-58.

Patterson, F., Tanner, J., \& Mayer, N. (1988). Pragmatic analysis of gorilla utterances: Early communicative development in the gorilla Koko. Journal of Pragmatics 12(1), 35-54.

Pollan, M. (2013). Cooked: A natural history of transformation. New York, New York: Penguin Books.

Pontius, J. U., Mullikin, J. C., Smith, D. R., Agencourt Sequencing Team, Lindblad-Toh, K., Gnerre, S., Clamp, M., Chang, J., Stephens, R., Neelam, B., Volfovsky, N., Schäffer, A. A., Agarwala, R., Narfström, K., Murphy, W. J., Giger, U., Roca1, A. L., Antunes, A., Menotti-Raymond, M., Yuhki, N., Pecon-Slattery, J., Johnson, W. E., Bourque, G., Tesler, G, NISC Comparative Sequencing Program, \& O’Brien, S.J. (2007). Initial sequence and comparative analysis of the cat genome. Genome Research 17, 16751689.

Sender, R., Fuchs, S., \& Milo, R. (2016). Revised estimates for the number of human and bacteria cells in the body. bioRxiv. Advance online publication.

doi:http://dx.doi.org/10.1101/036103 
Singer, P. (1975). Animal liberation. New York, NY: HarperCollins.

White, L. (2004). The historical roots of our ecological crisis. In R. S. Cottlieb (Ed.), This sacred Earth: Religion, nature, environment, 2nd ed. (pp. 192-201). New York: Routledge.

Wilkins, J. S. (2009). Species: A history of the idea. Berkeley, CA: University of California Press.

Zimmer, C. (n.d.). Genes Are Us. And Them. National Geographic. Retrieved from http://ngm.nationalgeographic.com/2013/o7/125-explore/shared-genes 